\begin{tabular}{|c|c|}
\hline $\begin{array}{l}\text { Sciendo } \\
\qquad \begin{array}{c}\text { RURAL SUSTAINABILITY RESEARCH 41(336), } 2019 \\
\text { ISSN - 2256-0939 } \\
\text { (c) Latvia University of Life Sciences and Technologies, } \\
\text { all rights reserved } \\
\text { http://www.llu.lv/en/ }\end{array}\end{array}$ & RUt \\
\hline
\end{tabular}

\title{
Linear Conformation Traits in Latvian Blue Cows in Relation to Possession to Gene Pool and Discarding
}

\author{
Ilga Šematoviča ${ }^{1},{ }^{*}$ Toms Martinsons ${ }^{1}$, Māris Līdaks ${ }^{2}$, Ināra Kanska \\ Latvia University of Life Sciences and Technologies ${ }^{1}$, Kristapa Helmaņa street 8, Jelgava, LV - 3004, Latvia \\ Animal Breeders Association of Latvia², Rīga, Latvia
}

\begin{abstract}
Latvian Blue (LZ) cows are kept for a variety of herd colors and because of national cow breed value. Resources of LZ cow breed remained low over the last decade. The aim of the study was to evaluate LZ cow breed linear conformation traits and analyze results in relation to their possession to the gene pool (GF) status and productive lifetime in 2017-2018. Information of the Agriculture Data Center Republic of Latvia (LDC) and linear evaluation in vivo were used. The number of LZ cows registered in LDC in 2017-2018 was 1648 and only 339 cows were gene-pool animals (LZ GF), and 140 of LZ GF animals were culled because of different reasons in 2017-2018. There were registered 544 (190 primiparous of them) closed standard LZ cow lactations in 2009 and only 292 (64 primiparous of them) in 2018. The oldest LZ GF cow was 16.3 years old; $20 \%$ of LZ GF cows were more than 10 years old, and only $10 \%$ were younger than 5 years. The overall exterior rating was established more than 80 points for $64.4 \%$ of the evaluated LZ GF cows. Some LZ GF linear conformation traits did not change significantly $(\mathrm{p}>0.05)$ with age - exterior, milking properties and cow's temperament. Udder parameters, rump and foot angle became worse with animals advancing in age and could be improved by breeding. No statistically significant differences $(p>0.05)$ were established regarding all parameters of conformation traits among LZ and LZ GF dairy cows except a tendency of larger body depth in LZ GF ( $\mathrm{p}=0.054$ ). In conclusion, the linear conformation traits of LZ cows, despite the presence of genetic influence of other breeds, do not differ significantly from the gene pool animals. Rump angle, udder and teat qualities became worse with age in LZ and LZ GF cows. Legs and hoofs were stable parameters inherited by the $\mathrm{LZ}$ offspring.
\end{abstract}

Key words: Latvian Blue cow, gene pool.

\section{Introduction}

Latvian Blue (LZ; Bos primigenius taurus) is endangered native cow breed in Latvia (Grīslis, 2006; Smiltina, Bāliņ̌̌ \& Grīslis, 2015). The LZ variety was mainly used for milk production. According to the research of the History Institute of the Latvian Academy of Sciences in the 40s of the 20th century, the $\mathrm{LZ}$ variety was practically extinct. After the World War II, the remaining LZ purebred animals were artificially inseminated (AI) with Latvian Brown (LB) bulls (Grinevičs, 2010). At the beginning of the 20th century, Paulis Lejiņ̌s, the first president of the Latvian Academy of Sciences, set the target to raise LZ cow breed from healthy and productive local cows which were adapted to the local climate conditions, feed and nutrition, with good health and productivity. These cows would produce not only more but also enough fat milk. At that time, the local cow productivity did not exceed $3,000 \mathrm{~kg}$ year ${ }^{-1}$ from cow with fat (MF) $4-4.3 \%$. As a result, to gain a higher milk yield, local cows were crossed with imported cattle breeds (Strautmanis, 2006). Other Latvian local breed Latvian Brown kept increasing its productivity until the 9th lactation (Cielava \& Jonkus, 2016).

In 2018, there were $1648 \mathrm{LZ}$ cows registered in LDC, but only 339 cows were gene pool (GF) animals, and 140 of LZ GF animals were culled because of different reasons 2017-2018. Productivity

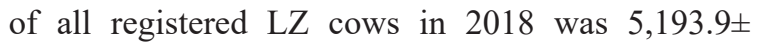
$1,317.37 \mathrm{~kg}$ year $^{-1}$ with milk protein (MP) $3.34 \pm$ $0.224 \%$ and MF $4.33 \pm 0.513 \%$, but LZ GF cow average milk yield was $5,381.2 \pm 1,857.08 \mathrm{~kg}$

\footnotetext{
* Corresponding Author's email: isem@inbox.lv
} 


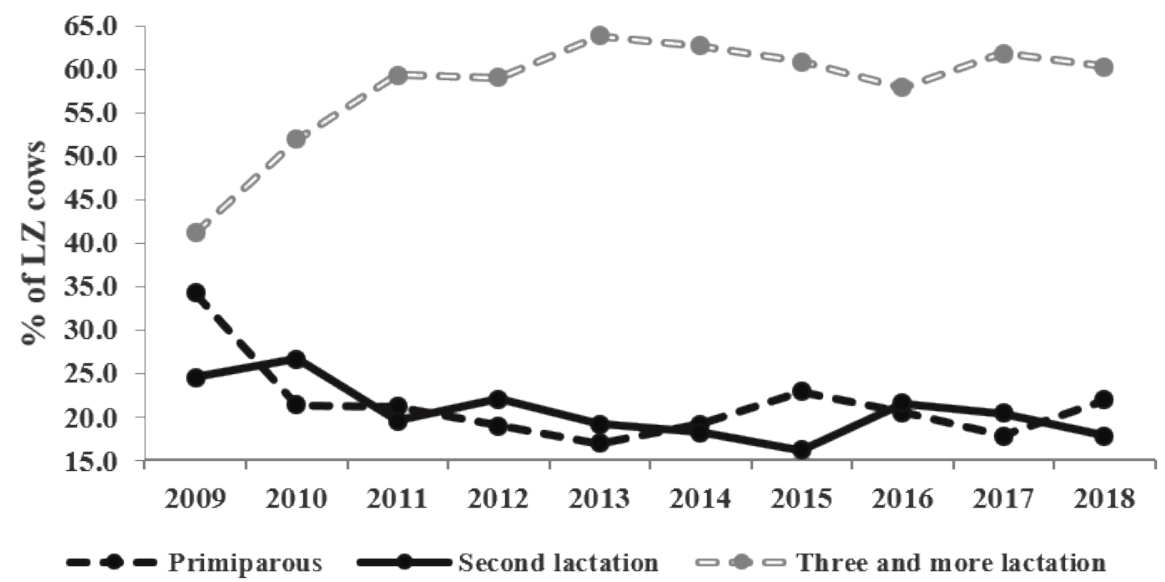

Figure 1. Population of LZ primiparous and older cows over the last ten years.

lactation $^{-1}$, MP $3.44 \pm 1.223 \%$, MF $4.23 \pm 1.564 \%$. Latvian native breed cows are adapted to local circumstances, modest feed and housing conditions. They are famous for their longevity (Sematovica, Antane \& Eihvalde, 2018). The oldest LZ cows in 2018 were: Olina, LV050050610075, was born on $08 / 06 / 1999$, it reached 18 years of age and had 14 lactations, its productivity was $6,971 \mathrm{~kg}$ year $^{-1}$, MP 3.29\%, MF 3.11\%, and LZ cow Dārta, LV024931314621, was born on 24/11/1999, reached 18 years and 5 months of age, it had 10 lactations with average productivity $5,126 \mathrm{~kg}$ year $^{-1}$, MP $3.38 \%$, MF $4.57 \%$. Twenty percent of LZ GF cows were more than 10 years old, and only $10 \%$ were younger than 5 years. Over the last ten years, the number of older LZ cows prevails (Figure 1).

Using data from LDC, the present research had calculated that LZ cows generally had a mean lifetime of $2704.3 \pm 1133.19$ days, or $7.7 \pm 3.24$ years. Interestingly, more than $32 \%$ of LZ cows have lived for more than 9 years, but more than $10 \%$ of $\mathrm{LZ}$ cows have lived for more than 10 years. The prewar Latvian officially registered LZ cow variety has survived due to their ability to adapt to the modest conditions of seagrass sandy meadows (Petrovska, Cielava \& Jonkus, 2017), the peculiar color of the hair and, of course, thanks to the enthusiasm of those cow breeders. These cows have good health, and no case of leukemia known so far. Animals are modest and able to reach a sufficiently high level of productivity in poorer ration. In recent years, attention was paid to investigation of LZ cows' linear conformation traits, health qualities, production and longevity (Petrovska, Cielava \& Jonkus, 2017).

Nowadays, the Latvian government has created a support program to preserve the LZ cow breed (Agriculture Data Center Republic of Latvia, 2019). A purposeful renewal of $\mathrm{LZ}$ cow breed regeneration began in the mid-1990s. Up to now, only AI and natural breeding were the methods to fulfil the program. Multiple ovulation (MO) and embryo transfer (ET) could allow obtaining superior genetic material based on creating genetically based couples. Thanks to ERAF project No. 1.1.1.1/16/A/025, BioReproLV, it is possible to promote the saving of LZ cow breed using multiple ovulation and embryo transfer (MOET).

The aim of the study was to evaluate Latvian Blue (LZ) cow breed linear conformation traits, and analyze results of their possession to the gene pool status and productive life time in 2017-2018.

\section{Material and Methods}

This work was done by analyzing information of the data base of the LDC and linear evaluation in vivo conducted by breeding specialists from Animal Breeders Association of Latvia and their certificated colleagues from March, 2017 to March, 2018. Linear conformation traits were evaluated and registered in the first and third lactation. The last evaluation registered in the LDC data base was taken into account. The data of the linear conformation traits such as exterior, stature, dairy form, body depth, chest width, rump, legs and hoofs, udder, teat, milking properties, temperament and body weight were analyzed in LZ, LZ GF and culled LZ GF cows. The number of $\mathrm{LZ}$ cow breed animals is diminishing. There were registered 544 (190 primiparous of them) closed standard LZ cow lactations in 2009 and 292 (64 primiparous of them) in 2018 (Figure 2).

Exterior total scores are calculated as follows: the coefficient for each conformation trait's group is determined: the cow general appearance and development - 30 points, legs and hoofs - 20 points, and udder - 50 points. Accordingly, the rating of each feature group is multiplied by a factor, divided by 100 and rounded to one decimal place. 


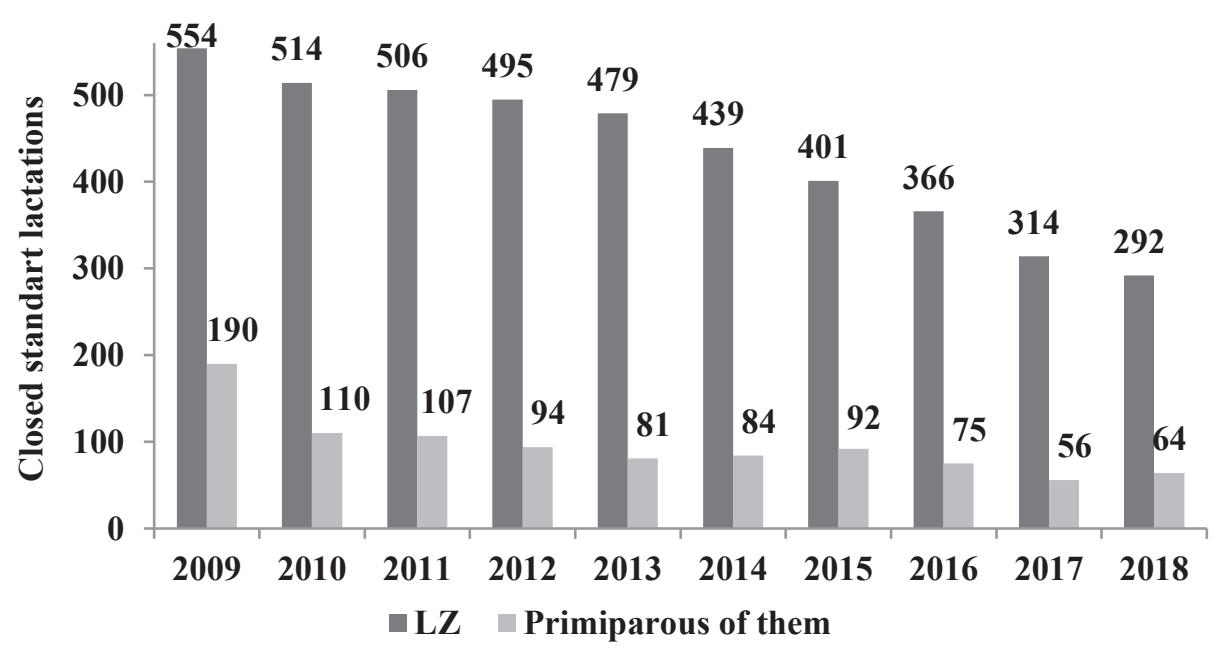

Figure 2. Dynamics of LZ cow number over the last decade.

All obtained results were processed using Exel and SPSS-21 programs (Arhipova \& Balina, 2003). Average, standard deviation, significance of differences $(p<0.05)$ for LZ GF cows $(n=314)$, LZ cows in general $(\mathrm{n}=1648)$, and culled LZ GF cows 2017-2018 $(\mathrm{n}=140)$ were calculated. Independent samples t-test and bivariate correlation (two-tailed) were conducted using SPSS-21.

\section{Results and Discussion}

Insufficient attention has been paid to develop this peculiar breed, especially to the improvement of exterior of this breed. The average of the exterior linear rating was well below the generally accepted optimum of standards for dairy cows (Table). The problem is due to the lack of availability of sires. The LZ population is too small and needs to focus on avoiding close couples.

The overall look of this cow breed is typical for dairy varieties, but these cows are relatively small in size. The body weight in LZ cows were established $541.2 \pm 66.84 \mathrm{~kg}$, LZ GF 545.8 \pm 69.61 , but the weight difference between them and that of the culled LZ GF cows, which were older, was statistically significant $569.9 \pm 59.54(\mathrm{p}<0.05)$. The same trend was found out regarding the stature.

Legs and hoofs were quite stable in this breed throughout their life and did not change significantly. Despite the presence of other breeds genetical influence, LZ breed cows maintain legs and hoofs like inherited properties.

Udder score had become worse through the productive life of cows, but it was not significant $(p>0.05)$. Dairy form and body depth were close to the optimal rating for the dairy cow. Chest width and rump width in this breed were intermediate and did not differ among LZ, LZ GF and culled LZ cows
( $>0.05)$; however, it was far from the optimal score 9 (wide) $(\mathrm{p}<0.05)$. Rump angle detected a slight slope, little below intermediate. It provides a more successful parturition and recovery process for the new reproductive cycle cyclicity. These cows have easier involution and subsequently better AI results. According to LDC information, pregnancy rate in LZ and LZ GF was similar, after $1.5 \pm 0.94$ and $1.5 \pm 0.87$ artificial insemination times, respectively. Generally, in $\mathrm{LZ}$ cows AI was $1.8 \pm 1.22$ times per pregnancy.

Rear legs side view was of a stable quality in LZ during their productivity life and it was inherited quality in offspring. Rear legs from the back were far from optimal score 9, they were quite severe toeout and had evaluating score around 5.5 points. A hoof angle in all evaluated LZ cows was quite close to the optimal $\left(45^{\circ}\right)$, and it was important that this parameter could persist throughout the cow's life. It could be provided due to not so big body weight of these cows.

LZ cows have intermediately acceptable fore udder attachment and it becomes worse with age. The udder's form is tending to be bowl-shaped, often with oblique bottom edge, formed already in the second to third lactation due to the weak attachment of the udder. Central ligament is slightly definite. The rear udder width and height is quite far from the optimal score 9. These qualities explain the modest productivity. Volumetric, smoothly developed udder with good blood supply is the basis for high milk yield because milk is synthesized in the tissues using the raw materials supplied to it by blood (Bionaz et al., 2012). Distant front but closer placed rear teats do not describe their suitability for automatic milking systems or robot milking. It is an important factor to properly obtain all milk in each milking time and maintain udder health (Slettbakk et al. 1995). 
Summary of conformation traits and their optimal values in LZ, LZ GF and culled LZ GF

Table

\begin{tabular}{|c|c|c|c|c|c|}
\hline \multirow{2}{*}{\multicolumn{2}{|c|}{ Parameters }} & $\mathrm{LZ}$ & LZ GF & LZ culled & \multirow{2}{*}{$\begin{array}{l}\text { Optimal } \\
\text { value }\end{array}$} \\
\hline & & \multicolumn{3}{|c|}{ Mean \pm stdev } & \\
\hline \multirow{3}{*}{ Exterior } & Overall look & $80.1 \pm 3.83$ & $81.5 \pm 4.04$ & $81.9 \pm 4.71$ & $90 / 100$ \\
\hline & Legs, hoofs & $80.1 \pm 3.57$ & $80.1 \pm 3.75$ & $80.2 \pm 3.57$ & $90 / 100$ \\
\hline & Udder (score) & $79.6 \pm 3.67$ & $79.7 \pm 3.78$ & $79.5 \pm 3.44$ & $90 / 100$ \\
\hline \multicolumn{2}{|c|}{ Stature $(\mathrm{cm})$} & $138.9 \pm 5.28$ & $138.9 \pm 5.23$ & $140.8 \pm 4.76$ & $\mathrm{x}$ \\
\hline \multicolumn{2}{|c|}{ Dairy form } & $5.9 \pm 0.58$ & $5.9 \pm 0.67$ & $5.8 \pm 0.57$ & 6 \\
\hline \multicolumn{2}{|c|}{ Body depth } & $6.9 \pm 0.67$ & $7.1 \pm 0.64^{\mathrm{a}}$ & $7.0 \pm 0.51$ & 7 \\
\hline \multicolumn{2}{|c|}{ Chest width } & $6.1 \pm 1.06$ & $6.1 \pm 0.92$ & $6.3 \pm 1.14$ & 9 \\
\hline \multirow{2}{*}{ Rump } & Rump width & $6.0 \pm 1.02$ & $5.9 \pm 0.95$ & $6.2 \pm 1.10$ & 9 \\
\hline & Rump angle & $4.8 \pm 0.88$ & $4.8 \pm 0.96$ & $4.5 \pm 1.03^{\mathrm{b}}$ & 5 \\
\hline \multirow{3}{*}{$\begin{array}{l}\text { Legs, } \\
\text { hoofs }\end{array}$} & Rear legs side view & $5.7 \pm 0.78$ & $5.7 \pm 0.80$ & $5.7 \pm 0.89$ & 5 \\
\hline & Rear legs from the back & $5.43 \pm 1.21$ & $5.4 \pm 1.23$ & $5.5 \pm 1.03$ & 9 \\
\hline & Hoof angle & $4.3 \pm 0.79$ & $4.3 \pm 0.81$ & $4.6 \pm 0.72^{b}$ & 5 \\
\hline \multirow{6}{*}{ Udder } & Udder front & $5.1 \pm 1.14$ & $5.1 \pm 1.15$ & $5.5 \pm 0.84^{b}$ & 9 \\
\hline & Udder depth & $4.7 \pm 1.17$ & $4.6 \pm 1.14$ & $4.4 \pm 1.23$ & 5 \\
\hline & Rear udder height & $5.4 \pm 1.03$ & $5.4 \pm 0.94$ & $5.2 \pm 1.06$ & 9 \\
\hline & Rear udder width & $5.6 \pm 1.02$ & $5.6 \pm 1.00$ & $5.9 \pm 1.02^{\mathrm{b}}$ & 9 \\
\hline & Central ligament & $5.4 \pm 0.89$ & $5.4 \pm 0.74$ & $5.1 \pm 1.0^{\mathrm{b}}$ & 6 \\
\hline & Fore udder attachment & $5.1 \pm 1.08$ & $5.1 \pm 1.13$ & $4.8 \pm 0.95^{\mathrm{b}}$ & 9 \\
\hline \multirow{3}{*}{ Teat } & Teat length & $5.5 \pm 1.08$ & $5.5 \pm 1.08$ & $5.6 \pm 0.99$ & 5 \\
\hline & Rear teat placement & $5.7 \pm 1.02$ & $5.7 \pm 1.10$ & $5.8 \pm 1.14$ & 5 \\
\hline & Front teat placement & $4.8 \pm 0.80$ & $4.8 \pm 0.80$ & $5.5 \pm 1.13^{\mathrm{b}}$ & 5 \\
\hline \multicolumn{2}{|c|}{ Milking properties } & $5.7 \pm 0.91$ & $5.6 \pm 0.91$ & $5.5 \pm 0.82$ & 7 \\
\hline \multicolumn{2}{|c|}{ Temperament } & $5.6 \pm 0.92$ & $5.6 \pm 0.83$ & $5.7 \pm 0.99$ & 8 \\
\hline \multicolumn{2}{|c|}{ Body weight (kg) } & $541.2 \pm 66.84$ & $545.8 \pm 69.61$ & $569.9 \pm 59.54^{b}$ & $\mathrm{x}$ \\
\hline
\end{tabular}

${ }^{\text {a }}$ significant difference between LZ, LZ GF and LZ culled $p<0.05$

${ }^{\mathrm{b}}$ significant difference between LZ GF and LZ, LZ culled $p<0.05$

The overall exterior rating was estimated to be more than 80 points for $64.4 \%$ of the evaluated LZ GF cows. Some LZ GF linear parameters did not change significantly $(\mathrm{p}>0.05)$ with age - legs and hoofs (except hoofs angle), udder score, dairy form, milking speed and cow's temperament. The rump angle, fore udder attachment, central ligament, udder front, front teat placement, rear teat position, rear udder width changed significantly $(\mathrm{p}<0.05)$ and became worse. There were no statistically significant differences $(p>0.05)$ regarding all parameters of the linear evaluation between LZ and LZ GF dairy cows except tendency of larger body depth in LZ GF ( $p=0.054)$.

The LZ breed cows are characterized by black hoofs which are more resistant than white hoofs, such as the Holstein breed and Swedish red cow breed. LZ breed cows have gained leg durability since they adapted to the local conditions of keeping; however, their shape and quality could be better (Petrovska, Cielava \& Jonkus, 2017).

In all LZ cows, the overall look correlated with conformation trait of legs and hoofs $(r=0.52 ; \mathrm{p}<0.01)$, udder score $(\mathrm{r}=0.54 ; \mathrm{p}<0.01)$, rump angle $(\mathrm{r}=0.52$; $\mathrm{p}<0.01)$, stature $(\mathrm{r}=0.52 ; \mathrm{p}<0.01)$, rear udder width $(\mathrm{r}=0.40 ; \mathrm{p}<0.01)$, and body weight $(\mathrm{r}=0.45 ; \mathrm{p}<0.01)$. Weak but statistically significant correlations were found related to the overall look and lactation $(\mathrm{r}=0.22$; $\mathrm{p}<0.05)$, milking type $(\mathrm{r}=0.20 ; \mathrm{p}<0.05)$. In LZ GF cows, correlations were found out between the overall look and legs and hoofs $(r=0.54 ; \mathrm{p}<0.01)$, udder score 
$(\mathrm{r}=0.51 ; \mathrm{p}<0.01)$, stature $(\mathrm{r}=0.53 ; 0<0.01)$, rump width $(\mathrm{r}=0.37 ; 0.01)$, udder front $(\mathrm{r}=0.28 ; \mathrm{p}<0.01)$, rear udder width $(\mathrm{r}=0.41 ; \mathrm{p}<0.01)$, and body weight $(\mathrm{r}=0.42 ; \mathrm{p}<0.01)$.

In the summer, LZ cows usually graze and they cover several kilometers a day. Over the generations, the natural selection of animals has survived. The most durable and resistant animals continue to pass the desirable qualities for future generations. Currently, the number of LZ breeding cows is rapidly decreasing, and hence the part of the animal population that is characterized by durable, healthy legs and hoofs is threatened.

Due to the depleted resources of the LZ GF, the use of modern technologies such as MOET should be applied to promote more effective, more intensive LZ number stabilization, preservation of the breed, and to promote the breeding program. This will ensure a more rapid multiplication of the most valuable LZ breed animals and eliminate the critical situation in terms of population size and diminishing genetic resources. The method is based on the possibility of using a genetically high-grade cow as an embryo donor.

It is important to multiply LZ cows with the best linear conformation traits.

\section{Conclusions}

1. Latvian Blue cows, despite the presence of genetic influence of other breeds, do not differ significantly from the Latvian Blue gene pool cows regarding the linear conformation traits.

2. Rump angle, udder and teat qualities worsen with age in LZ and LZ GF cows and could be improved by breeding.

3. Legs and hoofs are stable parameters which are inherited in LZ offspring.

4. Exterior, milking properties and cow's temperament do not change significantly with age. These are stable qualities for LZ cow breed.

\section{References}

1. Arhipova, I., \& Bāliņa, S. (2003). Statistika Ekonomikā. Risinājumi ar SPSS un Mikrosoft Exel (Statistic in economy. Resolution with SPSS and Microsoft Exel). Rīga, Datorzinību Centrs. 327 pp. ISBN 9984665194.

2. Bionaz, M., Hurley, W. \& Loor, J. (2012). Milk Protein Synthesis in the Lactating Mammary Gland: Insights from Transcriptomics Analyses. In: Milk proteins. Rijeka: InTech, p. 287-324.

3. Cielava, L. \& Jonkus, D. (2016). Piena produktivitāte un kvalitāte atkarībā no govju vecuma (Milk Productivity and Quality
Depending on Cow Age), Proceedings of Ražas svētki „Vecauce - 2016”: Lauksaimniecības zinātne nozares attīstībai, pp. 12-15., ISBN 9789984-48-240-8.

4. Damiran, D., Larson, K., Pearce, L., Erickson, N., \& Lardner, H. A. (2018). Effects of Heifer Calving Date on Longevity and Lifetime Productivity in Western Canada. Sustainable Agriculture Research; 7(4); 11-17. DOI: 10.5539/sar.v7n4p11.

5. Grinevičs, I. \& Grosvalds, I. (2006). Latvijas govju šķirņu izveidošana un Latvijas Zilās govs izzušana (Creation of Latvian Cow Breeds and Disappearance of the Latvian Blue Cow). http:// priede.bf.lu.lv/konf/apsek/zoo/2011/Grinevics Grosvalds Blue Cow.pdf, accessed 26.10.2018.

6. Griņevičs, I. (2010). Zilā govs atgriežas (The Blue Cow Is Returning). Vides Vēstis. Žurnāls par zalıo dzīvesveidu. Publicēts 2010.gada jūnijā. http://www.videsvestis.lv/zila-govs-atgriezas/, viewed 12.12.2018.

7. Grinevičs, I., \& Madžulis, V. (1993). Latvijas zilie lopi (Latvian Blue Cattle), SLU Rembate 1993, 34-145.lpp.

8. Grīslis, Z. (2006). Zilās govis Vidzemē (Blue Cows in Vidzeme). Jelgava. BŠSA "Zilā govs": 1- 36. (In Latvian)

9. Petrovska, S., Cielava, L., \& Jonkus, D. (2017). Tesmeņa lineārā vērtējuma ietekme uz piena produktivitāti un kvalitāti Latvijas vietējo šķirņu govīm (The Effect of Udder Conformation Traits On Latvian Native Dairy Cow Milk Productivity and Quality), Proceedings of the Scientific and Practical Conference Harmonious Agriculture, 23.02.2017., LLU, Jelgava, Latvia, 140-144. ISSN 2500-9451.

10. Sematovica, I., Antane, V., \& Eihvalde, E. (2018). Health Status in the Latvian Native Breed of Latvian Brown Dairy Cows That Are Intended for Multiple Ovulation and Embryo Transfer. Animal Reproduction, 15(3), 586, Jul./ Sept. 2018. ISSN 1806-9614.

11. Slettbakk, T., Jorstad, A., Farver T.B. \& Holmes, J.C. (1995). Impact of Milking Characteristics and Morphology of Udder and Teats on Clinical Mastitis in First- and Second-lactation Norwegian Cattle. Preventive Veterinary Medicine, Vol. 24, p. $235-244$

12. Smiltina, D., Bāliņš, A., \& Grīslis, Z. (2015). A Review of Latvian Blue (LZ) Cows from The List of Animal Genetic Resources in Latvia. Acta Biol. Univ. Daugavp., 15(151); 165-177. 2015 ISSN 1407 - 8953.

13. Agriculture Data Center Republic of Latvia (2019). 'Latvijas Zilās govju šķirnes 
saglabāšanas programma' (Latvian Blue Cow Breed Saving Program). Retrieved October 27, 2018, from http://www.ldc.gov.lv/upload/doc/ zilas_govis_2016-2026.pdf.
14. Strautmanis, D. (2006). Slaucamo govju šķirnes Latvijā (Dairy Cows in Latvia). No: Lauksaimniecības dzīvnieki un to produkcija biologiskajā lauksaimniecībā. Sigulda, 95.101. lpp. 